\title{
Improving Students' Achievement in Reading Comprehension \\ Through Learning Together Method
}

\author{
*Sundari Ulfa
}

\begin{abstract}
This study focuses on improving students' achievement in reading comprehension by applying the Learning Together Method. This research was conducted with an action research design. The subject of this study was the first year IPA students at SMA Nur Azizi Tanjung Morawa. The total number of students was 32 students. This research was performed in two cycles and every cycle consisted of three meetings. The quatitative data was collected through a reading test and the qualitative data through diary notes, observation sheets, and interview. The reading test showed that the score of the students improved continuously from pre test through post test 1 and post test 2 . The mean of the students' score in pre test was 60,5 . In post test 1 , the mean increased to 69,4 and in post test 2 , the score rose to 83 . The diary notes, observation sheets, and interview indicated that the students were eager and more active during teaching and learning process in the second cycle than in the first cycle. It was found that teaching reading through the Learning Together Method improved students' achievement. It is suggested that English teachers apply this method as one alternative in teaching reading comprehension.
\end{abstract}

Key Words: Learning Together Method, Reading Comprehension, Students' Achievement.

* A graduate of English Language and Literature Department of UNIMED 


\section{INTRODUCTION}

\section{Background of the Study}

Reading is one of the most important skills in language learning besides listening, speaking, and writing. In reading skill, the students are expected to be knowledgeable and familiar with what the teacher has explained in the context. It means that the students are expected to have more skills to explain the content of the text or passage after they comprehend the reading text. That is why the purpose of reading is to get some information from the text.

In learning English as a foreign language, students are expected to get some information from their readings. Since it is generally learned from the secondary level of education and higher education, the students are expected to comprehend a reading text as well as possible, but the students still face some problems to get information from their reading. These problems should be considered in the terms of the relevance of teaching method. Learning Together Method should be taken into consideration for teaching reading skill. This method will give the contribution to do some activities in comprehension. Through this method, the students can be more active in teaching and learning process, especially in teaching reading comprehension.

In teaching reading, the students cannot comprehend English text well. There are some factors why they cannot understand the text. There are students who do not have good motivation to read and they felt the text is not interesting for them because they must keep on looking up the words in a dictionary to find out the meaning of the words. These activities make them feel bored and uninterested in reading comprehension. So, it is a problem for the teacher in teaching reading comprehension in the class.

But in fact, based on the preliminary observation in SMA Nur Azizi Tanjung Morawa, when the writer called for The List of Students' Score (DKN/Daftar Nilai Siswa) for reading comprehension tests in three semesters, many students could not pass The Minimal Completeness Criterion (Kriteria Ketuntasan Minimum/KKM) applied by the school in English subject. Their DKN in three semesters are, as follows: 
Table 1.1 Students' Scores of Reading Comprehension Tests in Three Last Semesters

\begin{tabular}{|c|c|c|c|c|}
\hline Semester & Score & Students & Percentage & Mean \\
\hline \multirow{2}{*}{$1{ }^{\text {st }}$ Semester $2009 / 2010$} & $<64$ & 32 Students & $86.5 \%$ & \multirow{2}{*}{47.3} \\
\cline { 2 - 4 } & $\geq 64$ & 5 Students & $13.5 \%$ & \\
\hline \multirow{2}{*}{$2^{\text {nd }}$ Semester $2009 / 2010$} & $<64$ & 26 Students & $70.3 \%$ & \multirow{2}{*}{53.7} \\
\cline { 2 - 4 } & $\geq 64$ & 11 Students & $29.7 \%$ & \\
\hline \multirow{2}{*}{$1^{\text {st }}$ Semester $2010 / 2011$} & $<64$ & 35 Students & $87.5 \%$ & \multirow{2}{*}{49.8} \\
\cline { 2 - 4 } & $\geq 64$ & 5 Students & $12.5 \%$ & \\
\hline
\end{tabular}

The Minimal Completeness Criteria (KKM/Kriteria Ketuntasan Minimal) applied by school is 64 . From the data above, it can be concluded that the students' ability in reading comprehension in that class is still low. It can be seen from the mean of students' score where the mean is still under the Minimal Completeness Criteria. If as guidance is National Standard which is 5.50, so, many students fail in National Examination because reading comprehension tests in National Examination are more dominant.

The writer did the interview to some students in the class. Based on the interview, the writer concluded some problems faced by students in reading comprehension. First problem, students did not have motivation to read because the text is not interesting. The second problem was limited time. With the limited time and the long enough text, they must finish reading text and answer the following questions. So, they could not concentrate well because they feel chased by the time. The last problem was teaching method applied by the teacher. Many teachers still used the translation method where teacher only has students read the text and then translate the text. It made students feeling bored too. Those were some problems faced by students in the class.

Teacher said too in an interview in the preliminary observation, many problems were faced by students in studying English in the class. One of the problems was students didn't have motivation to study English. In students' mind, English was the difficult lesson. It was hard for them to understand the passage because there were a lot of unknown vocabularies. The next problem is their basic knowledge in English that is still low. In senior high school, many students didn't know about the simple grammar such as the using of "to be" and so on. Meanwhile, based on the curriculum applied in 
senior high school, students should be able to read, to write, to listen and to speak. But, in fact, they could do nothing in English. If just focusing on the grammar, of course, students will be left so long from the achievement expected by the curriculum.

Moreover, based on the writers' experience in Teacher Training Practice in SMP Negeri 1 Stabat, commonly teacher taught reading comprehension by using translation method too. They tended to translate their reading text in the initial stages of their teaching strategies. Firstly, teacher had students underline some difficult words then find out the meaning from the dictionary. Then teacher asked them to translate all the paragraphs in the text. After that, teacher asked them to analyze the generic structure of the text. These are suitable to problems faced by students based on the interview. In this case, teacher should make a suitable strategy in teaching reading comprehension in order to make the students interested.

Considering the condition above, the writer offers to apply Learning Together method to overcome the problems. Learning together method is one of the eight Cooperative Learning methods. It is one of the student team learning methods. There are 4-5 members in one group. In the application, this method is started by delivering learning purpose and learning material, group activity, quizzes and appreciation.

\section{Research Questions}

The problem of the study was formulated as the following: Does the effect of Applying Learning Together Method improve reading comprehension of the first year IPA students at SMA Nur Azizi Tanjung Morawa?

\section{Objective of the Study}

The objective of this study was to find out whether the effect of Applying Learning Together Method improves reading achievement of the first year IPA students at SMA Nur Azizi Tanjung Morawa.

\section{Significance of the Study}

By using group discussion in Learning Together method, it will : 
- help students to understand the text easily and well because in group, they can share ideas that they get after they have read the text.

- motivate the students to do best for their group. Therefore, in learning reading comprehension, both teacher and students can be more active to express their idea or opinion. In this case, Learning Together method can give good solution for teacher and students to get the education successful.

\section{Conceptual Framework}

\section{Students' Achievement in Reading Comprehension}

According to Hornby (1994:93) Achievement is a thing done successfully, especially with afford and skill. According to Bloom (1996:16) there are three aspects of learning achievement namely cognitive, affective knowledge and understanding psychomotor.

Cognition consists of knowledge, understanding, application, analysis, synthetic and evaluation. Application includes the method on concrete case. Analysis includes the ability to divide the small parts of whole. Synthetic includes combining the new theory into the new understanding and evaluation merits the ability to perform an opinion about something.

Affection is the changing of behavior that affects some one less to do something. There are acceptances; sign with the acceptance by using their sense are responds. Decision, decide a problem with a simple up to complex.

Psychomotor, the skill to do something, reading to do it based on physic and emotion, self control and become a habit. Therefore it can be concluded that the achievement is a successful in reaching particular goal, status and standard, especially by effort, skill, courage, etc.

Learning achievement has success for their aspects in reading. The students hopefully are able to get the good score in reading comprehension in narrative text. The categories that will be measured in reading narrative text are cognitive domain, namely knowledge, comprehension and application.

\section{Reading}


Reading is an important tool for people of many societies, allowing them to access information which might have otherwise been unavailable. Reading is a complex cognitive process of decoding symbols for the intention of deriving meaning (reading comprehension) and/or constructing meaning. Reading is a means of language acquisition, of communication, and of sharing information and ideas.

Reading is typically an individual activity, although on occasion a person will read out loud for the benefit of other listeners. Reading aloud for one's own use, for better comprehension, is a form of intrapersonal communication. Reading to young children is a recommended way to instil language and expression, and to promote comprehension of text.

Furthermore, conclusion of the definition of reading is the activity of people which used as tool in society to communication, and to share or to access

the information which might have otherwise been unavailable as a complex cognitive process of decoding symbols for the intention of deriving meaning.

According to Nunan (2003:68) reading is a fluent process of readers combining information from a text and their own background knowledge to build meaning. The goal of reading is comprehension. While Goodman (1976) and Smith (1982) writes that reading is the instantaneous recognition of various written symbols, simultaneous association of these symbols with existing knowledge and comprehension of the information and ideas communicated. At the time a reader interacts with printed media, his prior knowledge combined with the print and the visual (written) information result in his comprehending the message. The conclusion of those experts above is that reading is the process to understand and interact with the text which consists of many symbols to get the information from the text and build the meaning by background knowledge of the readers with the comprehension as a goal.

In English as a second language, reading is an essential skill for learners of English as a second language. For most of these learners it is the most important skill to master in order to ensure success not only in learning English, but also in learning in any content class where reading in English is required. With strengthened reading skills, learners will make greater progress and development in all other areas of learning. 
Reading is about comprehending, that is, the construction of meaning. Readers construct meaning by interacting with the text (Pearson, Roehler, Dole and Duffy, 1990) on the basis of their existing or prior knowledge about the world (Rumelhart, 1980). For many years (including the 1970s), reading comprehension instruction was based on a concept of reading as the application of a set of isolated skills such as finding main ideas, identifying cause and effect relationships, comparing and contrasting, and sequencing. It was thought that comprehension could be taught by providing specific instruction in these discrete skills (National Reading Panel, 2000; Texas Education Agency, 2002).

Reading comprehension is the heart and goal of reading, since the purpose of all reading is to gather meaning from the printed page. If a student says words in a passage without gathering their meaning, one would hesitate to call that reading.

\section{Reading Comprehension}

The reading comprehension is viewed by most linguists as composed of a multiple number of skills and abilities that are interrelated and interdependent. Therefore, reading comprehension need some skills to make students' effectiveness as readers.

Reading comprehension is a skill that must be developed and can be only developed by means of extensive and continual practices. Grellet (1986:3) states that reading comprehension is a skill to understand a written text by extracting the required information may be explicit or implicit. It means that reading comprehension is a process to get some information explicit or implicit.

Otto (1979:241) states that in comprehending reading text, readers have to find the main ideas to obtain the message. In other words, finding the main ideas will determine the quality of their reading comprehension. It means that in reading comprehension, the reader is expected to understand fully the reading material. The reader should be able to give a clear explanation about the reading material when he/she is asked some questions concerning the ideas contained there. If he is able to do, so we can say that he/she has already understood the reading material. 
Reading comprehension involves taking meaning to a text in order to obtain meaning from that text (Turner, 1988). An individual may be said to comprehend a text fully when he can:

1. Recognize the words and sentences of the text and know what these words and sentences mean (obtain literal meaning).

2. Associate meanings, both denotative and connotative, from personal experiences with the printed text (obtain inferential meaning).

3. Recognize how all these meanings and/or his perceptions of them fit together contextually.

4. Make value judgments about, and based on, the reading experience (read critically).

To understand reading comprehension one should begin by analyzing, what comprehension involves and how it relates to the entire reading process. Smith (1975:185) contends that fluent reading entails two fundamental skills: (1) prediction of meaning and the "sampling" of surface structure sufficiently to make predictions certain and (2) making the most, efficient use of visual information, which is all the cues to meaning avail-able in the printed text. Smiths position is that a student learns to read by reading materials in which he has an opportunity to test hypotheses. As a student becomes better able to predict or hypothesize what the text will say, he becomes a better reader.

The ability to decode or translate printed symbols into understood language is a prerequisite for comprehension. LaBerge and Samuels (1974:2) state that students cannot simultaneously give adequate attention to both decoding and comprehension. It means that decoding must become more or less automatic for complete comprehension. Once the decoding process is automatic, the reader can give major attention to understanding.

Comprehension is an unobservable mental process. At least two questions about comprehension are important to the reading teacher: (1) How does reading comprehension take place, what goes on in the reader's head?, and (2) What teaching strategies and techniques will bring about optimal growth in reading comprehension?. It means that in reading comprehension, it is very important to know the strategies or technique which is used in teaching reading process. 


\section{Levels of Comprehension}

Levels of comprehension mean how the students understand the information gotten from the text and which level that has been achieved. According to Burns (1984:177), there are four levels of reading comprehension. They are literal comprehension, interpretative comprehension, critical comprehension and creative comprehension. For students' in the senior high school, the levels of comprehension that they must mastery are Literal comprehension and inferential comprehension.

Literal Comprehension is lowest level in reading comprehension. Reading for literal comprehension, which involves acquiring information that is directly stated in concerns in main ideas, details, causes and effect also sequences understanding of vocabulary, sentences and paragraph meaning, etc.

There are two types of tasks in training students in literal comprehension. They are recognition task and recall task. Students are required to identify the main points in the reading selection in recognition task. In recall talk, students are required to produce memory explicit statement from selection.

Inferential comprehension involves reading between the lines or making inferences. It is the process of deriving ideas that are implied rather than directly stated. Skills for inferential reading include: inferring main ideas in which the main ideas not directly stated, inferring the topic, detecting mood, detecting the author's purpose in writing, drawing conclusion.

From some explanation above, we can say that inferential comprehension is the ability to go to beyond what is stated directly, to understand the writer means by looking for the inside meaning. It can be also meant the ability to get inference or implied meaning from the text. Inferential comprehension is more difficult than literal comprehension level because reader must either understand the text well enough and more on personal insight.

\section{Learning Together Method}

Learning together is one of various methods available in Cooperative Learning. So, learning together method is under umbrella of Cooperative Learning. Among the most widely used Cooperative learning methods are those developed and researched by David and Roger Johnson and their colleagues at the University of Minnesota. Learning Together emphasized four elements (Johnson, Johnson, Holubec, and Roy, 1984): 
1. Face-to-face interaction: students work in four-to-five member groups.

2. Positive interdependence: students work together to achieve a group goal.

3. Individual accountability: students must show that they have individually mastered the material

4. Interpersonal and small-group skills: students must be taught effective means of working together and of discussing how well their groups are working to achieve their goals.

Learning together is similar to STAD in that day use heterogeneous learning groups and emphasizes positive interdependence and individual accountability. However, they also highlight team building and group self-assessment, and recommend team grades rather than certificates or other recognition.

\section{Effectiveness of Learning Together Method}

Learning Together methods have been compared to traditional methods and have been found to produce the following outcomes:

1. Enhanced academic achievement to high, average, and low achieves.

2. Improved face relations and other social relationship.

3. Greater acceptance of mainstreamed students.

4. Improved self-esteem.

5. Better attitudes toward the subject and toward school in general.

6. Improved time-on-task.

Since the sample of this study is the students of Senior High School, those characteristics are good in learning with friends. So, the method is quite well to use. It is so because one of the Learning Together Method is enhanced academic achievement to high, average, and low achievers. 


\section{METHODOLOGY}

\section{Research Design}

Action research was conducted in this study. Watts (1985:118) states that action research is a process in which participants examine their own educational practice systematically and carefully, using the techniques of research. Simply, it is a term used to describe professionals studying their own practice in order to improve it. Action research can be applied by teacher to improve students' achievement in the class. This action research is called by classroom action research or Educational action research.

In general, classroom action research activities involve repeated cycles, each consisting of planning, acting, observing, and reflecting. To do action research is to plan, act, observe and reflect more carefully, more systematically, and more rigorously than teaching process that is usually done in every life and to use the relationships between these moments in the process as source of both improvement and knowledge. The action researcher will carry out of the four activities collaboratively, involving others affected by the action.

\section{Subject}

The subject of this research was the first year students of SMA Nur Azizi Tanjung Morawa class XI-IPA consists of 32 students.

\section{Data Collection}

This research involved qualitative data the quantitative data. The qualitative data were obtained from the mean of students in reading test taking multiple choices. The qualitative data were obtained from the diary note, questionnaire sheet, observation sheets, and interview students. The data were taken from XI-IPA ${ }^{2}$ class which consisted of 32 students. It was accomplished in two cycles. Every cycle consisted of four steps of action research (planning, action, observation and reflection). Each cycle was conducted for three meeting. So, there were six meeting for this research.

From the data in the table, it can be seen that the mean of students' score in reading narrative text by applying Learning Together Method kept increasing. It begins only 60.5 in orientation test. Next, it was improved come 69.4 . Then, in post test, it was 
improved again become 83. The fact showed that the students' score in narrative reading was improved after the students have been taught to read narrative text by using Learning Together Method.

The qualitative data were taken from observation sheet, diary notes and interview report. The observation sheet was aimed to describe the situation, the responds of the students and the teacher's attitudes during teaching-learning process (See Appendix B). The observation sheet which was done in the last meeting was aimed to know the students' opinion about the application of Learning Together method in improving students' achievement in reading comprehension (See Appendix D). The diary note was aimed to know the writer's personal evaluation about the situation during teaching learning process. It was done in every meeting (See Appendix E).

\section{Data Analysis}

This research was conducted in six meetings, included orientation meeting. In orientation meeting, Learning Together method was not applied yet. The teacher just gave a text to every student. Then they had to read the text and then they had to answer the following questions related to the text individually. In the first cycle to the second cycle, Learning Together method was applied as the writer had planned in lesson plan.

From the collected data (quantitative and qualitative data), Learning Together methods were able to improve students' achievement in reading comprehension. It can be showed by the mean score and standard deviation of students' scores in the following figure; 


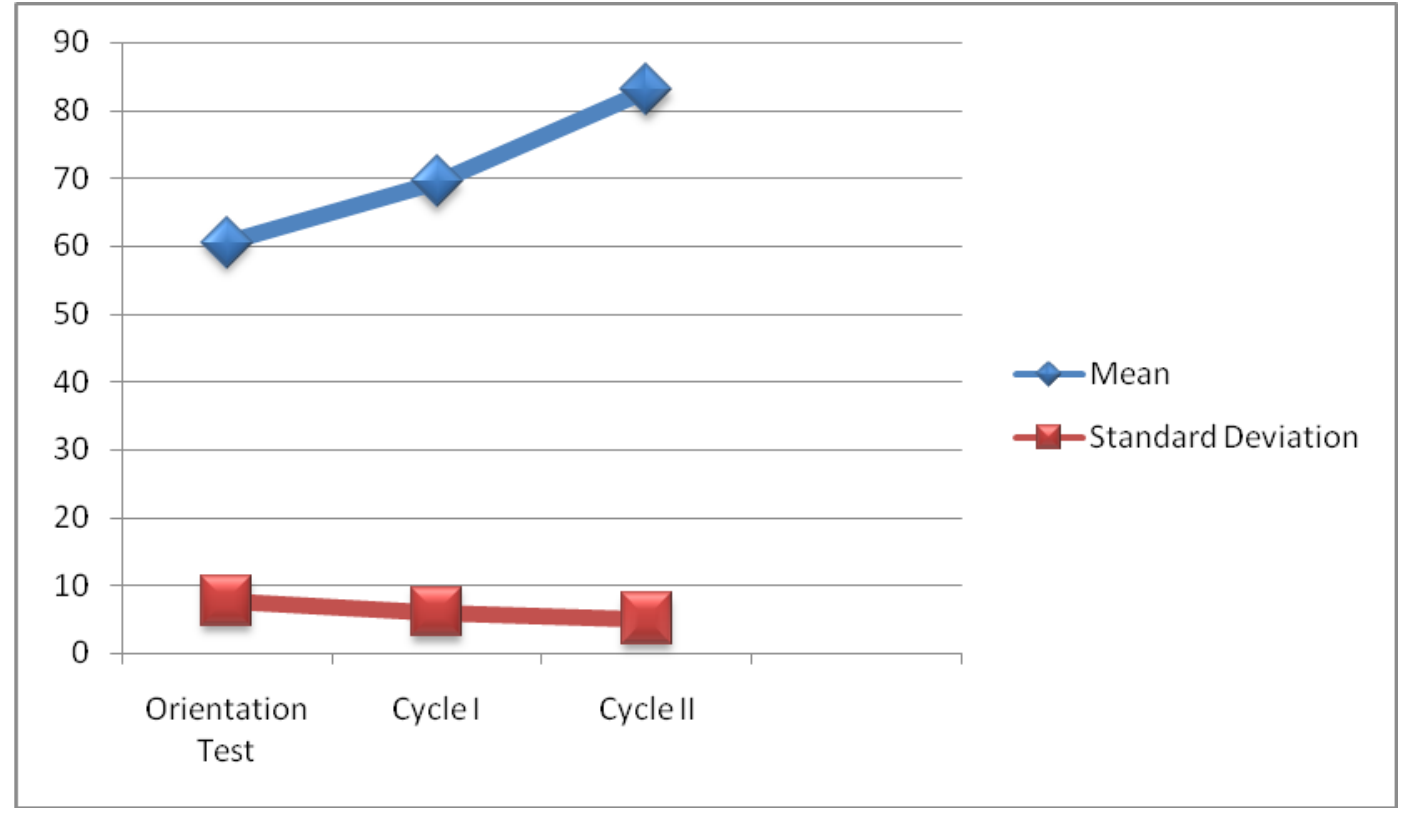

The Development Students' Mean Score and Standard Deviation

The figure showed that mean score of every test increased significantly from the first cycle to the second cycle. The lowest mean score was in first cycle (before applying Learning Together method). And the highest score mean was in second cycle. In the first cycle, students' score was heterogeneous. And in the second cycle, students' score tended more homogenous. It could be reflected by standard deviation that decreased in every cycle. The improvement could be showed too by comparing the lowest and highest score from every test. It could be showed by following table and figure;

The improvement of students' achievement

\begin{tabular}{|l|l|l|l|}
\hline $\begin{array}{l}\text { Types of } \\
\text { Score }\end{array}$ & Orientation Test & $\begin{array}{l}\text { Post Test in Cycle } \\
\mathbf{1}\end{array}$ & $\begin{array}{l}\text { Post Test in Cycle } \\
\mathbf{2}\end{array}$ \\
\hline Lowest Score & 46 & 60 & 72 \\
\hline Highest Score & 74 & 82 & 95 \\
\hline Average Score & 60,50 & 69,40 & 83 \\
\hline N & 32 & 32 & 32 \\
\hline
\end{tabular}




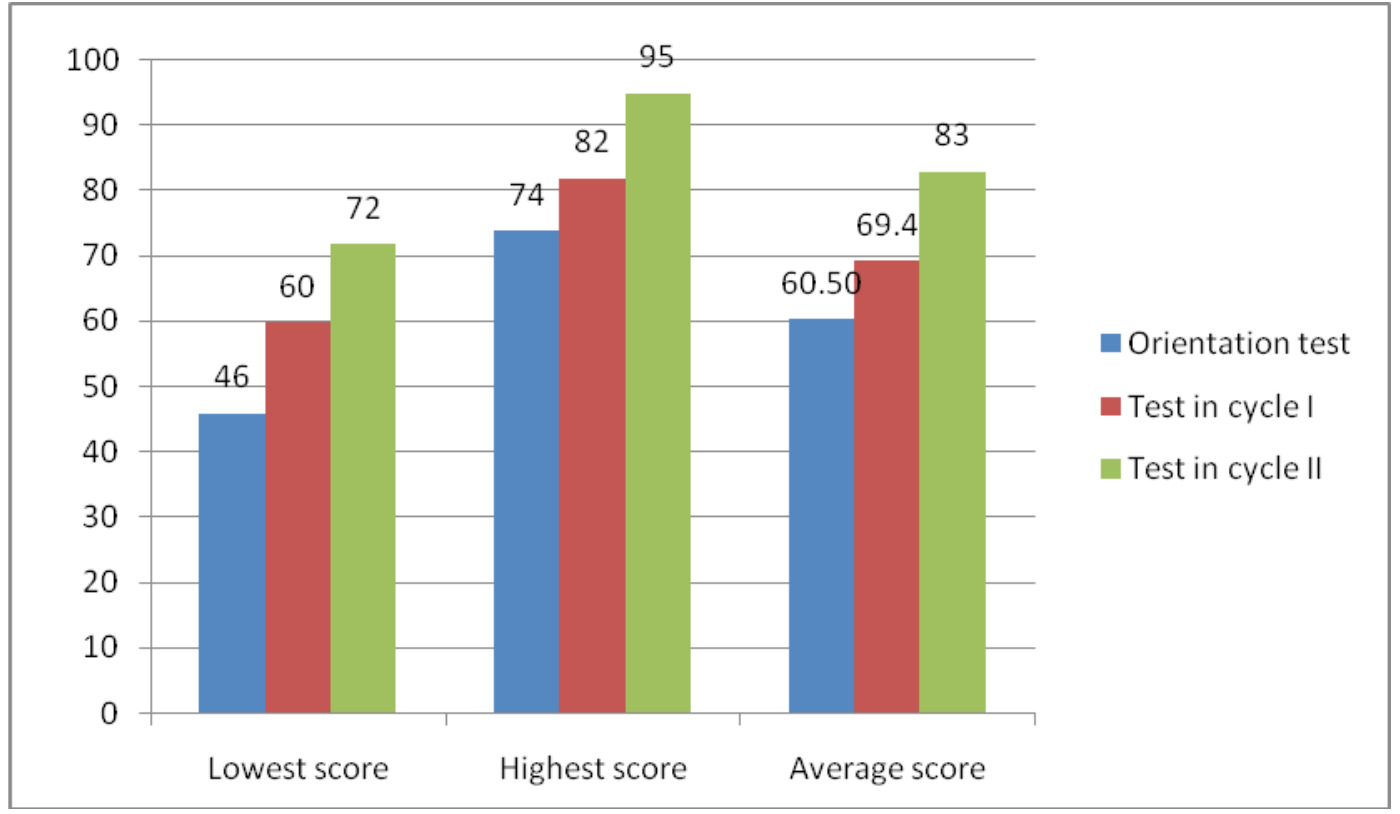

The Improvement of Students' Achievement

From the table and the figure above, it could be seen that there was improvement on students' achievement from test to test. For example: the lowest score improved from 46 to 72 . It could also see from the average score of the students that had been improved from 60.50 to 83 . So, the table showed that Learning Together method had given improvement on students' reading narrative text.

In this research, the indicator as successful achievement of students in reading narrative text was if the $75 \%$ of students have got score up to 75 in their reading tests. The number of students who were competent in reading narrative text was calculated by applying the following formula:

$$
P=\frac{R}{T} \times 100 \%
$$

Where: $\quad \mathrm{P}$ : the percentage of those who get the points up to 75

$\mathrm{R}$ : the number of those who get the points up to 75

$\mathrm{T}$ : the total number of students

The percentage of the students' improvement in reading narrative text can be seen as follows: 
$P_{1}=\frac{0}{32} \times 100 \%=0,2 \%$

$P_{2}=\frac{7}{32} \times 100 \%=21,8 \%$

$P_{3}=\frac{31}{32} \times 100 \%=96,8 \%$

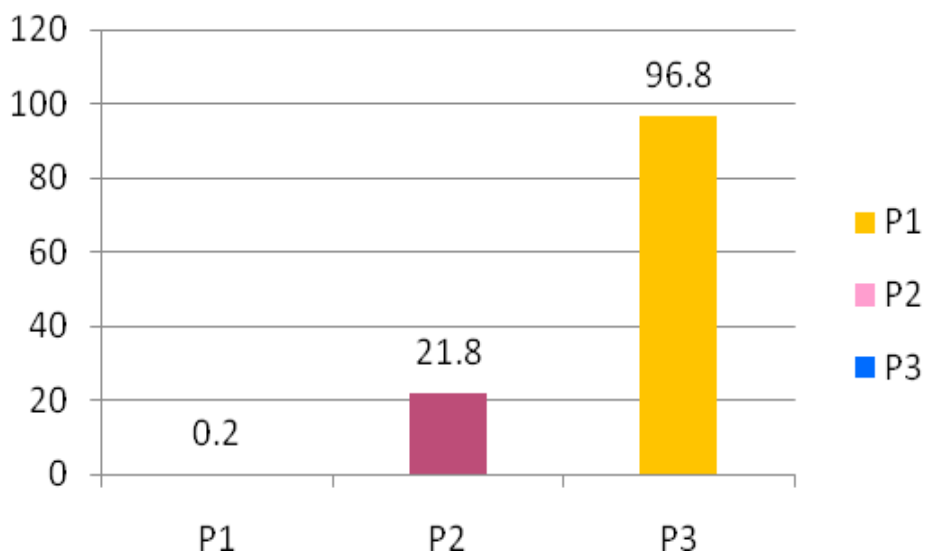

The data performed that there were no students who got points up $75 \%$ in the orientation test. In contrast, there was increasing percentage of students' reading competence when Learning Together Method was applied in the teaching and learning process. In the first cycle, $21.8 \%$ students who got points up to $75 \%$. In the end, there were $96.8 \%$ students who got points up 75. So, it was concluded that Learning Together Method worked effectively and efficiently in improving students' reading in narrative text.

\section{RESULTS AND DISCUSSION}

The result of research indicated that there was an improvement on the students' reading comprehension, which was taught by Learning Together method. It was proved by data, which showed that the mean of the students' scores increased significantly from cycle I to cycle II. In orientation test, the mean was 60.4 , in cycle I was 69.4 , in cycle II was 83. Standard deviation in orientation test was 7.7, cycle I was 6.1 and cycle II was 5.1. It could be seen from standard deviations that they decreased significantly in every test.

As the quantitative data, the researcher also elaborated the quantitative data which were got from diary notes, observation sheet and interview report. All the 
quantitative data showed that step by step, students become more active and enthusiast in receiving the material during teaching and learning process. The questionnaire and interview report also informed that most students strongly agree if the teacher apply this method for teaching reading. From the qualitative and quantitative data, it is found that the application of Learning Together method had successfully improved students' achievement in reading comprehension.

According to David and Roger Johnsons' (1994) Learning Together models of cooperative learning are probably the most widely used of all cooperative methods, and have been evaluated in the largest number of studies.

Learning Together method applied in the class was more effective in improving students' achievement in reading comprehension than the method used by the teacher. It could be showed in the first test in which mean scores were low before Learning Together method applied. But after applying Learning Together method in the class, mean score increased significantly. The highest score improvement were in the first cycle. In this cycle, students' scores tended heterogeneous. It means that mean score did not spread well. Although their score increased significantly, their scores were still under $75(\mathrm{KKM})$. It occurred because teacher in first cycle could not control well and students were quite enthusiastic in this cycle. In group discussion, some students were active in discussing about the text. But, many students chatted in the group and also disturbed their friend in their own group and other group. In class presentation, teacher explained the material so fast, so it made students could not catch the knowledge well. Again, students were ashamed in asking about the material which they did not know. So, it influenced their understanding about the text.

It was contrast in second cycle. Many students' score were up to 75. And also the mean score in this cycle was higher than in the first cycle. Students' score started homogenous. Many students got score around mean score. It was a proof that, there was an improvement in this cycle. Students' activities in their class were more active than first cycle. In group discussion, many students involved actively. Many students begun enthusiastic in applying of Learning Together method in reading comprehension. The teacher explained the material not so fast. So, it helped students in understanding about the material. It was something proper if their scores in second cycle were higher than in the first cycle. But, there was something strange in this cycle. Some students got the 
score decline. In this cycle, students getting decline score were not active. They talked with their friends in group and also disturbed other students. Therefore, the writer conducted third cycle to improve all the students' scores. So, that all students' scores were up to 75 (KKM).

The writer expectation in the second cycle could be reflected in the third cycle. All students' scores were improved and up to 70. The mean score was the highest one from other cycles. Students' scores were more homogenous than previous cycle. In this cycle, they were more active and enthusiastic in studying reading comprehension by applying Learning Together method. All the members were involved actively in group discussion. The teacher explained the material clearly. From some explanations above can be concluded that Learning Together in reading comprehension is able to improve students' achievement and students' interest, enthusiastic and motivation in reading comprehension.

\section{CONCLUSION AND SUGGESTIONS}

Based on the result of the study, the conclusions are dawn as follows:

1. There is an improvement of students' reading comprehension if it is taught by using Learning Together method. It is showed by the mean of the students' scores: orientation test (60.94), cycle I (69.4) and cycle II (83).

2. The class is more homogenous after applying Learning Together Method. It is showed by standard deviation of students' scores: orientation test (7.7), cycle I (6.1) and cycle II (5.1).

3. The students felt more enjoyable and interested in learning reading comprehension by applying Learning Together Method. It is showed by their enthusiasm in reading comprehension in two cycles and their respond while they were asked about reading comprehension. 


\section{REFERENCES}

Artz, A.F., \& Newman, C. M. 1990. Cooperative Learning. New York: The McGrawHill Companies.

Brown, H.D. 2001. Principles of Language Learning and Teaching. New York: Longman.

D’Angelo, F. 1980. Process and Thought in Composition. Boston : Winthrop.

Fiechnter, L., \& Davis, M. 1991. Groupworthy Tasks: When Four Heads are Better than One. Educational Leadership, VOL LX, 6, 1-6.

Harmer, J. 2001. The Practice of English Language Teaching. (3rd Ed). England: Longman.

Johnson, D., \& Johnson, R. 1998. Learning Together and Alone. NJ: Prentice Hall.

Kemmis, S., \& McTaggart, R. 1986. The Action Research Planner. Victoria: Deakin University.

Khairunisak, S. 2007. The Effect of Teaching SQ3R Technique on Students' Achievement in Reading Comprehension [Bachelor's thesis]. Medan: State University of Medan.

LaBerge, D., \& Samuels, S. 1974. Toward a Theory of Automatic Information Processing in Reading. New York: International Reading Association.

Lunsford, A. 2001. The Everyday Writer. Boston: Bedford/ST. Martin's.

Mc. Crimmon, J. 1984. Writing with a Purpose. Boston: Houghton Miffin. 
Metzke, L., \& Berghoff, P. 1999. Cooperative Learning in the Classroom. Washington : A. S. Canter.

Oakley, B. 2003. Coping with Hitchhikers and Couch Potatoes on Teams. http://ctl.stanford.edu/Tomprof/postings/441.html. Retrieved December 18, 2007.

Otto, W. 1979. How to Teach Reading. New York: Aldison Wesley.

Richards, J.C., \& Rodges, T. S. 2001. Approaches and Methods in Language Teaching; Description and Analysis. London : Cambridge University Press.

Simanjuntak, M. 2005. The Correlation of Language Function on Students' Reading Comprehension [Bachelor's thesis].. Medan: State University of Medan.

Smith, J. 1975. Comprehension and Learning. New York: Holt, Rinehart and Winston.

Turner, T. 1988. Comprehension: Reading for Meaning: Teaching Reading. London: Scott Foresman. 